\title{
Identification of Turkish and standard apple rootstocks by morphological and molecular markers
}

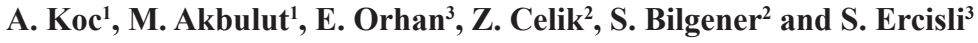 \\ ${ }^{1}$ Black Sea Agricultural Research Institute, Gelemen-Samsun, Turkey \\ ${ }^{2}$ Department of Horticulture, Faculty of Agriculture, \\ Ondokuz Mayis University, Samsun, Turkey \\ ${ }^{3}$ Department of Horticulture, Faculty of Agriculture, \\ Ataturk University, Erzurum, Turkey \\ Corresponding author: S. Ercisli \\ E-mail: sercisli@hotmail.com
}

Genet. Mol. Res. 8 (2): 420-425 (2009)

Received February 12, 2009

Accepted March 4, 2009

Published April 14, 2009

\begin{abstract}
Two local (Vezir-1 and Vezir-2) and two standard (M9 and MM106) clonal apple rootstocks were compared using both morphological and molecular markers. International Union for the Protection of New Varieties of Plants criteria were used for morphological evaluation, which did not clearly separate these rootstocks. We tested 47 random decamer primers for random amplified polymorphic DNA analysis; 15 of them gave reproducible polymorphic patterns, yielding 109 bands, which showed $78 \%$ polymorphism. Based on a dendrogram obtained by unweighted pair group method using arithmetic average analysis, three clusters were obtained. The highest genetic similarities were found between M9 and Vezir-2 (0.670). The random amplified polymorphic DNA markers proved to be more efficient than the standard morphological markers for the identification of rootstocks.
\end{abstract}

Key words: Malus; Genetic diversity; UPOV; Rootstocks; Turkey; Random amplified polymorphic DNA 


\section{INTRODUCTION}

The commercial apple industry worldwide is in the midst of a major change in fruit production management systems. With size-controlling rootstocks, tree size has been reduced and the number of trees per hectar, referred to as tree density, has increased significantly. More recently, the standard apple cultivars in Turkey are also mainly budded on clonal rootstock. In other words, seedling apple rootstocks have been replaced in spite of their heterogeneity in Turkey (Ercisli et al., 2006). As it is well known, rootstocks influence several aspects of fruit tree growth and development, including yield and fruit quality (Webster, 1995; Filho et al., 2007). Rootstocks also affect the trees' resistance to drought, root pests, and diseases (Beckman and Pusey, 2001; Sharma and Sharma, 2008; Thomidis and Exadaktylou, 2008). Rootstocks determine the relative size of the trees. With the currently available commercial rootstocks, there is a wide range in tree size potential as well as some resistance to certain root-borne insects and disease problems.

The terms "dwarf tree" or "dwarfing rootstock" are frequently used to describe the trees smaller than regular size. Currently, dwarfing rootstocks are more common in apple and sweet cherry. The majority of size-controlling apple rootstocks originated in England. The "M" prefix refers to the East Malling Research Station in England, where much of the initial research was conducted in the early 1900s. The "MM" prefix, Malling-Merton, refers to hybrid trees of the Malling series crossed with "Northern Spy" in Merton, England, in the 1920s (Rom and Carlson, 1987).

The existence of a very large number of rootstocks reinforces the need for a reliable verification system to identify them properly by the nurserymen and also the growers. This represents a very important aspect in the fruit industry, as initial planting and establishing orchards incur huge investments of time and money (Oliveira et al., 1999). Accurate identification of rootstocks is also essential for patent protection of these materials.

Random amplified polymorphic DNA (RAPD) markers have proven to be a reliable marker system for genetic fingerprinting and also to determine the genetic relationships among germplasm collections. RAPD markers have the advantages of simplicity and the ability to detect relatively small amounts of genetic variation and also need no prior information on the genome. The technique has already been successfully applied to identify different rootstocks belonging to sweet cherry (Lisek et al., 2006), apple (GonzálezHorta et al., 2005), citrus (Schäfer et al., 2004), and grape (Tamhankar et al., 2001).

In this study, we report on the use of morphological and molecular markers for estimating genetic relationships in four clonally propagated apple rootstocks.

\section{MATERIAL AND METHODS}

Leaf samples from two local (Vezir-1 and Vezir-2) and two standard (M9 and MM106) dwarf apple rootstocks were collected in Samsun Province. Samsun Province is located on the Black Sea coast of northern Turkey. The leaves were stored immediately at $-80^{\circ} \mathrm{C}$ for DNA extraction.

Genomic DNA was extracted from powdered (ground in liquid nitrogen) plant materials using a modified method described by Lin et al. (2001). Approximately 10-15 $\mathrm{mg}$ tissue samples from each plant sample were snap-frozen in liquid nitrogen in $2-\mathrm{mL}$ 
Eppendorf tubes. A volume of $1000 \mu \mathrm{L}$ DNA extraction buffer [100 mM Tris-HCl, $\mathrm{pH}$ 8.0; $50 \mathrm{mM}$ EDTA, $\mathrm{pH} 8.0 ; 500 \mathrm{mM} \mathrm{NaCl} ; 2 \% \mathrm{SDS}(\mathrm{w} / \mathrm{v}) ; 2 \%$ 2-mercaptoethanol (v/v), $1 \% \mathrm{PVP}(\mathrm{w} / \mathrm{v})]$ was added and mixed well. The mixture was incubated at $65^{\circ} \mathrm{C}$ in a water bath for 40 min with intermittent shaking at 5 -min intervals. The mixture was centrifuged at $12,000 \mathrm{~g}$ for $15 \mathrm{~min}$ at $4^{\circ} \mathrm{C}$. The supernatant was transferred to a clean $1.5-\mathrm{mL}$ tube, mixed with an equal volume of phenol:chloroform:isoamyl alcohol $(25: 24: 1)$, and was centrifuged. The supernatant was collected and mixed with $1 / 10$ volume $10 \%$ CTAB- 0.7 $\mathrm{M} \mathrm{NaCl}$ in a clean tube. After centrifugation, the supernatant was collected and an equal volume of chloroform:isoamyl alcohol (24:1) was added and mixed gently. The DNA was precipitated by the addition of 0.6 volume of freezer-cold isopropanol, for $10 \mathrm{~min}$ at $-20^{\circ} \mathrm{C}$. The DNA was pelleted by centrifugation $(12,000 \mathrm{~g}$ for $10 \mathrm{~min})$ and the isopropanol was poured off; the DNA was allowed to air-dry before being dissolved in $100 \mu \mathrm{L}$ TE buffer.

The samples were screened for RAPD variation using the standard 10-base primers supplied by Operon. A $30-\mu \mathrm{L}$ reaction cocktail was prepared as follows: $10 \mathrm{X} 3.0 \mu \mathrm{L}$ buffer, $1.2 \mu \mathrm{L}$ dNTPs $(10 \mathrm{mM}), 1.2 \mu \mathrm{L}$ magnesium chloride $(25 \mathrm{mM}), 2.0 \mu \mathrm{L}$ primer $(5$ $\mu \mathrm{M}), 0.4 \mu \mathrm{L} \mathrm{Taq}$ polymerase (5 unit), $19.2 \mu \mathrm{L}$ water, and $3.0 \mu \mathrm{L}$ sample DNA (100 ng/ $\mu \mathrm{L}$ ). A total of 20 RAPD primers were tested in this study, and the polymorphisms obtained with the primers are shown in Table 2.

The thermocycler (Eppendorf Company) was programmed as follows: $2 \mathrm{~min}$ at $95^{\circ} \mathrm{C} ; 2$ cycles of $30 \mathrm{~s}$ at $95^{\circ} \mathrm{C}, 1 \mathrm{~min}$ at $37^{\circ} \mathrm{C}, 2 \mathrm{~min}$ at $72^{\circ} \mathrm{C} ; 2$ cycles of $30 \mathrm{~s}$ at $95^{\circ} \mathrm{C}, 1$ min at $35^{\circ} \mathrm{C}, 2 \mathrm{~min}$ at $72^{\circ} \mathrm{C}$; 41 cycles of $30 \mathrm{~s}$ at $94^{\circ} \mathrm{C}, 1 \mathrm{~min}$ at $35^{\circ} \mathrm{C}, 2 \mathrm{~min}$ at $72^{\circ} \mathrm{C}$; followed by a final 5 -min extension at $72^{\circ} \mathrm{C}$, then brought down to $4^{\circ} \mathrm{C}$.

The markers were checked twice for their reproducibility.

The polymerase chain reaction products $(27 \mu \mathrm{L})$ were mixed with $6 \mathrm{X}$ gel loading buffer $(3 \mu \mathrm{L})$ and loaded onto an agarose $(1.5 \% \mathrm{w} / \mathrm{v})$ gel in $0.5 \mathrm{X}$ TBE (Tris-borate-EDTA) buffer, and electrophoresed at $70 \mathrm{~V}$ for $150 \mathrm{~min}$. The gel was stained in an ethidium bromide solution ( $2 \mu \mathrm{L} / 100 \mathrm{~mL} 1 \mathrm{X}$ TBE buffer) for $40 \mathrm{~min}$, and the bands were visualized under UV in a Bio Doc Image Analysis System with the Uvisoft analysis package (Cambridge, UK).

The positions of scorable RAPD bands were transformed into a binary character matrix (' 1 ' for the presence and ' 0 ' for the absence of a band at a particular position), which was entered in the RAPDistance computer program (Armstrong et al., 1994). These data were used for the calculation of pairwise genetic distances among cultivars using the Jaccard coefficient. The computer program calculated the degree of genetic dissimilarity between each pair of the 12 cultivars using the simple equation: $\mathrm{JC}=1-a /(a+b+c)$, where " $a$ " is the number of bands shared by plant " $x$ " and plant " $y$ ", " $b$ " is the number of bands in plant " $x$ ", and " $c$ " is the number of bands in plant " $y$ ". The Jaccard coefficient ignores the absence of matches. The distance matrix was used for cluster analysis using the unweighted pair-group method with arithmetic averages.

\section{RESULTS}

The morphological results are given in Table 1 and the molecular results are summarized in Table 2, Figure 1 and Figure 2. 
Table 1. The most distinct morphological characters of rootstocks.

\begin{tabular}{lcccc}
\hline UPOV criterion & Vezir-1 & Vezir-2 & M9 & MM106 \\
\hline Leaf length (mm) & 80 & 110 & 105 & 59 \\
Leaf width (mm) & 40 & 44 & 33 & 60 \\
Petiole length (mm) & 25 & 30 & Strong & Very strong \\
Pubescence (on upper half of shoot) & Medium & Medium & Low & Medium \\
Number of lenticels on shoot & High & Low & Red brown & Dark brown \\
Predominant color on shoot & Medium brown & Medium brown & Big & Medium \\
Size of bud on shoot & Medium & Small & Slightly held out & Ad pressed \\
Position of bud relative to axis on shoot & Slightly held out & Ad pressed & Small & Medium \\
Size of bud support on shoot & Small & Medium & Red & Long \\
Color of growing tip on shoot & White & White & Medium & Medium \\
Leaf blade length & Medium & Long & Medium & Medium \\
Leaf blade width & Narrow & Large & Straight & Concave \\
Leaf blade ratio length/width & Large & Concave & Round & Saw-toothed \\
Leaf blade profile in cross-section & Concave & Round & Weak & Strong \\
Leaf blade incisions of margin & Round & Weak & Medium & Long \\
Pubescence on lower side on leaf blade & Medium & Medium & Medium & Large \\
Petiole length & Short & Small & & \\
Stipule size & Small & & &
\end{tabular}

Table 2. List of the selected primers and the degree of polymorphism obtained among four apple rootstocks.

\begin{tabular}{|c|c|c|c|c|c|c|}
\hline Primer code & $\begin{array}{l}\text { Sequence } \\
5^{\prime} \rightarrow 3^{\prime}\end{array}$ & $\begin{array}{l}\text { Size (bp) } \\
\text { (min-max) }\end{array}$ & $\begin{array}{c}\text { Polymorphic } \\
\text { bands }\end{array}$ & $\begin{array}{l}\text { Monomorphic } \\
\text { bands }\end{array}$ & Total & $\begin{array}{c}\text { Percentage of } \\
\text { polymorphic markers }\end{array}$ \\
\hline OPA-1 & CAGGCCCTTC & $160-750$ & 6 & - & 6 & 100 \\
\hline OPA-2 & TGCCGAGCTG & $150-750$ & 8 & 1 & 9 & 89 \\
\hline OPA-4 & AATCGGGCTG & $300-1250$ & 5 & 3 & 8 & 63 \\
\hline OPA-12 & TCGGCGATAG & $160-530$ & 6 & 2 & 8 & 75 \\
\hline OPA-13 & CAGCACCCAC & $640-950$ & 4 & - & 4 & 100 \\
\hline OPH-14 & ACCAGGTTGG & $390-1000$ & 3 & 3 & 6 & 50 \\
\hline OPH-17 & САСТСТССТС & $250-1250$ & 3 & 1 & 4 & 75 \\
\hline OPH-18 & GAATCGGCCA & $450-1000$ & 6 & 3 & 9 & 67 \\
\hline OPH-19 & CTGACCAGCC & $250-950$ & 7 & 2 & 9 & 78 \\
\hline OPY-7 & AGAGCCGTCA & $260-1500$ & 9 & 4 & 13 & 69 \\
\hline OPY-11 & AGACGATGGG & $240-1000$ & 5 & 3 & 8 & 63 \\
\hline OPY-15 & AGTCGCCCTT & $300-750$ & 5 & - & 5 & 100 \\
\hline OPY-16 & GGGCCAATGT & $280-650$ & 7 & 1 & 8 & 88 \\
\hline OPW-17 & GTCCTGGGTT & $390-1100$ & 4 & 1 & 5 & 80 \\
\hline OPW-18 & TTCAGGGCAC & $250-1000$ & 7 & - & 7 & 100 \\
\hline Polymorphism (average) & & & & & & 78 \\
\hline Total & & & 85 & 24 & 109 & \\
\hline
\end{tabular}

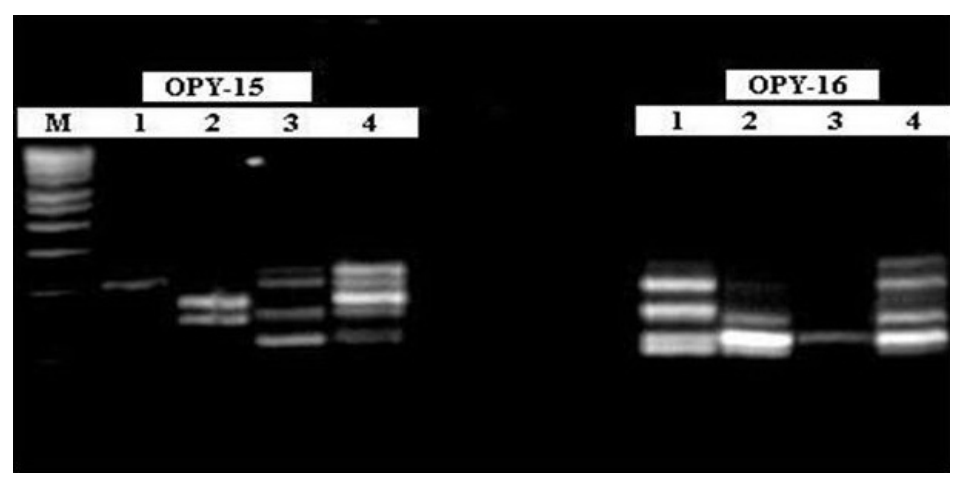

Figure 1. Representative random amplified polymorphic DNA profile of four apple rootstocks with primers OPY-15 and OPY-16. Lane 1 = M9; lane 2 = MM106; lane 3 = Vezir-2; lane $4=$ Vezir-1. $M=$ molecular marker. 


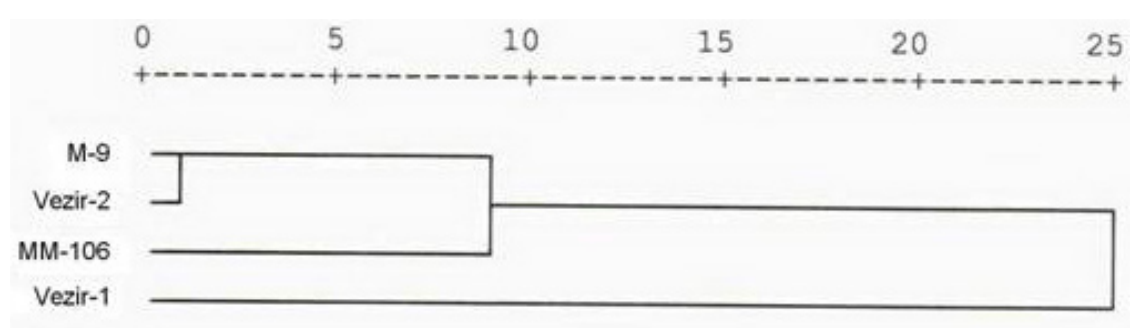

Figure 2. Unweighted pair-group method with arithmetic average dendrogram of four apple rootstocks based on 9 random amplified polymorphic DNA primers.

A total of 32 UPOV criteria were used (UPOV, 1999) to compare the rootstocks, and 18 of 32 criteria were found to be informative. The rest of the 14 criteria gave the same results. These 18 informative criteria and the compared results are given in Table 1. Among the rootstocks, Vezir-2 had the longest leaf length $(110 \mathrm{~mm})$, whereas MM106 had the greatest leaf width $(60$ $\mathrm{mm})$. MM106 also had very strong pubescence on the shoots. Vezir-1 and Vezir-2 had medium pubescence on the shoots. The number of lentisels on the shoots was highest in Vezir-1 and Vezir-2, and M9 had the lowest number of the lentisels on the shoots. The color of the growing tip on the shoots was white in Vezir-1 and Vezir-2, red in M9 and green in MM106. The stipula size was small in Vezir-1 and Vezir-2, medium in M9 and large in MM106 rootstocks (Table 1).

A total of 47 decamer oligonucleotide primers were used to investigate four apple rootstock samples. However, 32 primers did not produce any polymorphic bands or did not amplify clear products. As a result, 15 primers that produced good and reproducible polymorphic bands among the four apple rootstock samples were used for further analysis. A total of 109 fragments were amplified with a varying number per primer (Table 2), among which 24 fragments were monomorphic and 85 fragments showed polymorphism (Table 2). The size of the amplified fragments ranged from 150 to $1500 \mathrm{bp}$. Each primer generated 4 to 13 RAPD bands, and $78 \%$ of the bands were polymorphic.

The dendrogram obtained from the RAPD markers grouped the four rootstocks into three main clusters. The first cluster includes Vezir-2 and M9, the second cluster includes MM106 and the last cluster includes Vezir-1. The highest similarities were observed between Vezir-2 and M9 (0.670), and the lowest similarities were observed between Vezir-1 and MM106 (0.320).

\section{DISCUSSION}

Our study showed that according to UPOV criteria, it is difficult to classify rootstocks into groups. Each rootstock revealed a different behavior within the same criteria, and when we used the next morphological criteria, the behavior of rootstocks also changed, making it impossible to classify rootstocks into groups using morphological parameters.

However, the RAPD markers were found to be more effective in grouping apple rootstocks.

Previously, RAPD markers were also found to be more useful for discriminating apple cultivars (Stark-Urnau, 2002) and rootstocks (González-Horta et al., 2005) over morphological markers. Differences in the results obtained from grouping with RAPD markers and with the morphological characters were also reported in other fruit crops such as strawberry (Garcia et al., 
2002), mulberry (Vijayan et al., 2006) and pomegranate (Sarkhosh et al., 2006). This disagreement between molecular and morphological data could be attributed to a number of reasons; one is the effects of different climatic conditions on morphological traits, which do not influence RAPD markers (Kumar, 1999; Gupta and Rustgi, 2004). It is known that some mutational changes could easily be expressed phenotypically, such as fruit color and shape, but that may not affect the primer binding sites. Garcia et al. (2002) reported that tree size, shape and branching habit may not be detectable by the application of molecular markers. It should also be noted that post-transcriptional modifications and non-nuclear inheritance of some characteristics can cause the lack of fitting of morphological markers with molecular markers (Gupta and Rustgi, 2004; Sarkhosh et al., 2006).

\section{REFERENCES}

Armstrong J, Gibbs A, Peakall R and Weiller G (1994). The RAPDistance Package. Australian National University, Canberra.

Beckman TG and Pusey PL (2001). Field testing peach rootstocks for resistance to Armillaria root rot. HortScience 36: 101-103.

Ercisli S, Esitken A, Orhan E and Ozdemir O (2006). Rootstocks used for temperate fruit trees in Turkey: an overview. Sodininkyste ir Darzininkyste 25: 27-33.

Filho FDAM, Espinoza-Nuez E, Stuchi ES and Ortega EMM (2007). Plant growth, yield, and fruit quality of 'Fallglo' and 'Sunburst' mandarins on four rootstocks. Sci. Hort. 114: 45-49.

García MG, Ontivero M, Diaz Ricci JC and Castagnaro A (2002). Morphological traits and high resolution RAPD markers for the identification of the main strawberry varieties cultivated in Argentina. Plant Breed. 121: 76-80.

González-Horta AC, Fernandez-Montes MR, Rumayor-Flores A, Tostado EC, et al. (2005). Diversidad genética en poblaciones de manzano en Querétaro, México revelada por marcadores RAPD (Genetic diversity in apple populations from Queretaro, Mexico revealed by RAPD markers). Rev. Fitotec. Mex. 28: 83-91.

Gupta PK and Rustgi S (2004). Molecular markers from the transcribed/expressed region of the genome in higher plants. Funct. Integr. Genomics 4: 139-162.

Kumar LS (1999). DNA markers in plant improvement: an overview. Biotechnol. Adv. 17: 143-182.

Lin RC, Ding ZS, Li LB and Kuang TY (2001). A rapid and efficient DNA minipreparation suitable for screening transgenic plants. Plant Mol. Biol. Rep. 19: 379a-379e.

Lisek A, Korbin M and Rozpara E (2006). Simple identification of sweet cherry rootstocks PHL using RAPD markers. Sodininkyste ir Darzininkyste 25: 316-321.

Oliveira CM, Mota M, Monte-Corvo L, Goulão L, et al. (1999). Molecular typing of Pyrus based on RAPD markers. Sci. Hort. 79: 163-174.

Rom RC and Carlson RF (1987). Rootstocks for Fruit Crops. John Wiley \& Sons Inc., New York.

Sarkhosh A, Zamani Z, Fatahi R and Ebadi A (2006). RAPD markers reveal polymorphism among some Iranian pomegranate (Punica granatum L.) genotypes. Sci. Hort. 111: 24-29.

Schäfer G, Bastianel M and Dornelles ALC (2004). Genetic diversity of citrus rootstocks based on RAPD marker analysis. Cienc. Rural 34: 1437-1442.

Sharma S and Sharma N (2008). Rootstocks affect growth, water relations, gas exchange, and anatomy of 'Flemish Beauty' pear under water stress. J. Hortic. Sci. Biotechnol. 83: 658-662.

Stark-Urnau M (2002). Use of RAPD-markers in Malus domestica (apple) and Pyrus communis (pear) for cultivar identification - Part I: Malus domestica (apple). Erwerbsobstbau 44: 139-144.

Tamhankar SA, Patil SG and Rao VS (2001). Assessment of the genetic diversity of some important grape genotypes in India using RAPD markers. Vitis 40: 157-161.

Thomidis T and Exadaktylou E (2008). Susceptibility of 30 cherry (Prunus avium) genotypes to the bacterium Pseudomonas syringae pv. syringae. New Zealand J. Crop Hortic. Sci. 36: 215-220.

UPOV (Union for the Protection of New Varieties of Plants) (1999). International Union for the Protection of New Varieties of Plants. Apple Rootstocks, 99-03-24, TG/163/3.

Vijayan K, Tikader A, Kar P, Srivastava P, et al. (2006). Assessment of genetic relationships between wild and cultivated Mulberry (Morus) species using PCR based markers. Genet. Resour. Crop Evol. 53: 873-882.

Webster AD (1995). Rootstock and interstock effects on deciduous fruit tree vigour, precocity, and yield productivity. New Zealand J. Crop and Hortic. Sci. 23: 373-382.

Genetics and Molecular Research 8 (2): 420-425 (2009)

CFUNPEC-RP www.funpecrp.com.br 